\title{
Likumības princips civilprocesā: formālas lietu vešanas kārtības pamats civillietās
}

\author{
Dr. iur. Ivars Kronis \\ ORCID: 0000-0003-0673-0496 \\ Rìgas Stradina universitāte, Juridiskā fakultāte, Latvija \\ ivars.kronis@rsu.lv
}

\section{Kopsavilkums}

Rakstā tiek apskatîts jautājums par likumības principa izpausmi un saturu civilprocesā. Pētỉjumā tiek aplūkoti likumības principa procesuālie un materiāli tiesiskie jautājumi.

Atslēgvārdi: civilprocess, tiesvedība civillietās, likumības princips.

\section{levads}

Civilprocess ir universāls subjektīvo tiesību aizstāvības piespiedu veids jeb, citiem vārdiem sakot, civilprocess ir civilo tiesību piespiedu îstenošanas kārtība, kas tiek reducēta uz tiesību normu kopumu, kas nosaka gan esošo tiesību aizstāvības institūciju, gan personu, kuras izmanto šo aizstāvību vai kā citādi ir iesaistītas tajā, rīcības veidu. Šajā kārtībā būtisku vietu ieṇem tieši likumỉba. Ar likumību saprot tādu sabiedrības dzīves stāvokli, kurā, pirmkārt, ir tiesiskais regulējums, kurā nav loǵisku pretrunu un kurš kopumā atbilst šĩs sabiedrības objektīvām vajadzībām, un, otrkārt, fiziskās un juridiskās personas ciena, kā arī ievēro pieñemtās tiesību normas. Civilprocesā tas ir ne tikai princips, bet arī viens no tiesas procesa mērḳiem. Saskaṇā ar tā saturu likumības princips ietver, pirmkārt, prasību, lai tiesas pareizi piemērotu materiālo tiesību normas un veiktu procesuālas darbības atbilstoši tiesību normām; otrkārt, prasību, lai citi procesa dalībnieki ievērotu procesuālo un materiālo tiesisko regulējumu, iztiesājot un izskatot civillietas tiesā. Tādējādi likumības princips ietver procesuālās un materiāli tiesiskās sastāvdaḷas.

Raksta mērķis ir likumības principa morāli tiesiskā satura civilprocesā analīze, izvērtējot tā piemērošanas aspektus. 
Pētỉjuma materiāls un metodes ir šādas: empīrisko bāzi veido zinātniskie darbi un rakstu krājumu materiāli, publikācijas periodiskajos izdevumos un pirmavoti, tiesību akti, interneta resursi, kā arī cita publiski pieejamā informācija. Pētỉjuma izstrādē tika izmantota analītiskā, induktīvā un deduktīvā pētniecības metode.

\section{Likumības principa procesuālais saturs}

Civilprocesa likums [2] (turpmāk - CPL) tika pieṇemts 1998. gada 14. oktobrī un ir spēkā kopš 1999. gada 1. marta. Likumïbas principa pamats rodams CPL 1. panta otrajā daḷā, kurā noteikts, ka personai, kas vērsusies tiesā, ir tiesības uz tās lietas izskatīšanu tiesā likumā noteiktajā procesuālajā kārtībā. Citiem vārdiem sakot, tiesa drīkst izspriest civillietas tikai likumā noteiktajā kārtībā, kuru sauc par tiesvedību civillietās (civilo tiesvedību) jeb civilprocesu. Civiltiesības (civilās tiesības) ir materiālas tiesības, kas regulē indivīdam piemītošo subjektīvo tiesību rašanos, izmaiṇas, pāreju citām personām un izbeigšanos. Savukārt visas procesuālās tiesības, tostarp arī civilprocesuālās, pieder publiskajām tiesībām [16, 23-24]. Tādējādi, tiesai izskatot un izškirirot lietas, kas nodotas tās jurisdikcijai, ir stingri jāievēro likumā noteiktā darbības procesuālā forma, tas ir, kārtība, kādā, piemēram, tiek noteiktas personas, kuras piedalās lietā, notiek procesa uzsākšana, paziņošana procesa (lietas) dalībniekiem un to izsaukšana, lietas sagatavošana iztiesāšanai tiesā, tiesas sēdes, kā arī tiesas nolēmumu pārsūdzēšana un citas darbības. Tāpēc civilprocess ir formāla lietu vešanas kārtība civillietās.

CPL 2. pantā ir paredzēts, ka civillietas tiesa izspriež kārtībā, kas noteikta CPL un likumā "Par tiesu varu" [4] (turpmāk - LPTV). Civilprocesā tiesvedības gaita un civilprocesa institūti tiek regulēti galvenokārt katras valsts nacionālajos procesuālajos tiesību aktos, taču atsevišḳas procesuālās normas tiek iestrādātas arī starp materiāla rakstura normām. Turklāt pastāv iespēja, ka likumdevējs divos likumos var ietvert pat vienāda satura normas [14]. Lìdz ar to arī materiālo tiesību avoti satur atsevišḳas procesuālo tiesību normas, tomēr kopumā tiem ir tikai subsidiāra nozīme procesuālo jautājumu regulēšanā $[18,27]$.

Civilprocesa tiesību normas attiecas ne tikai uz noteiktu laiku, bet arī uz noteiktu tiesību telpu un noteiktu personu loku, ko teorijā sauc arī par tiesību normu spēka "dimensijām" [18, 22].

Civilprocesa tiesību normu spēks laikā: tiesvedība civillietās notiek pēc procesa likuma, kurš ir spēkā lietas izskatī̌̌anas, atsevišķu procesuālo darbību izdarǐ̌̌anas vai tiesas nolēmuma izpildīšanas laikā neatkarīgi no tā, kad izcēlies tiesiskais strīds un kad ierosināta civillieta, un kādu civilprocesa stadiju tā sasniegusi (CPL 3. pants). Tiesību zinātnē, skaidrojot procesuālā likuma piemērošanu laikā, norādīts, ka "jaunais procesuālais likums, tiklīdz tas stājies spēkā, tūliṇ arī piemērojams turpmākajām procesuālajām darbībām, kaut arī prasības lieta iesākta pirms jaunā likuma izdošanas. Nepieciešams vienīgi, lai jaunais procesuālais likums nepārgrozìtu un neatṇemtu pusei procesā tādas procesuālās tiesības, kuras viṇai bijušas lietas iesākšanas brīdī tiesā” [17, 128; 15]. 
Augstākā tiesa, skaidrojot jautājumu par CPL grozījumu intertemporālo piemērošanu, ir norādījusi, ka atbilstoši CPL 3. pantam tiesvedību civillietā reglamentē tās procesuālo tiesību normas, kas ir spēkā attiecīgās procesuālās darbības izdarīšanas laikā [6]. Jaunais procesuālais likums, tiklīdz tas stājies spēkā, tūliṇ arī piemērojams turpmākām procesuālām darbībām, kaut arī prasības lieta iesākta pirms jaunā likuma izdošanas $[17,128-129 ; 21,22]$.

Civilprocesa tiesību normu spēks telpā: tiesvedība civillietās visās Latvijas tiesās neatkarīgi no teritoriālās atrašanās vietas notiek saskaṇā ar Latvijas Republikas tiesību aktiem. Turklāt Latvijas tiesu spriedumi civillietās, kas stājušies likumīgā spēkā, ir obligāti visiem un izpildāmi visā valsts teritorijā [18, 16-17]. Latvijas tiesu nolēmumus var izpildīt arī ārvalstīs, ja šo valstu tiesas ir atzinušas nolēmumu par izpildāmu saskaṇā ar valstu starpā noslēgtajiem starptautiskajiem līgumiem un Eiropas Savienības (turpmāk - ES) tiesību normām.

Civilprocesa tiesību normu spēks attiecībā uz personu: civilprocesa tiesību normas vienlïdz attiecas gan uz visiem Latvijas Republikas pilson,iem un nepilsoniem, gan uz ārvalstniekiem un bezvalstniekiem. Visas šìs personas bauda vienādas civilprocesuālās tiesības, un tām ir vienādi civilprocesuālie pienākumi. Turklāt visas šo personu civillietas tiek izskatītas vienā un tajā pašã likumā noteiktajā procesuālajā kārtībā. Tādējādi šis procesuālais līdztiesības princips pilnīgi attiecas arī uz juridiskajām personām neatkarīgi no to atrašanās vietas Latvijā, īpašuma veida un pakḷautības $[18,24]$.

Civilprocesa tiesību normu piemērošanā tiesā izšḳir vairākas savstarpēji saistìtas stadijas:

1) tiesas sēdē konstatēto faktisko lietas apstākḷu analīzi;

2) tiesību normu izvēli un to tiesiskā sastāva atbilstības lietas apstākḷiem novērtēšanu;

3) tiesas nolēmuma kā tiesību normu piemērošanas akta pien̦emšanu. Ja tiesību normu saturs ir neskaidrs, tad tiesai jāveic attiecīgo tiesību normu iztulkošana, izmantojot interpretācijas pamatmetodes, t. i., noskaidrojot tiesību normas jēgu ar gramatiskās vai filolog̣iskās metodes, vēsturiskās metodes, sistēmiskās metodes vai teleoloğiskās metodes palīdzību $[18,28]$.

\section{Likumības principa materiāli tiesiskais saturs}

CPL 5. panta pirmajā dạ̦ā noteikts, ka tiesa izspriež civillietas saskaṇā ar likumiem un citiem normatīvajiem aktiem, Latvijas Republikai saistošajām starptautiskajām un ES tiesību normām (sk. arī LPTV 18. pantu).

Ja starptautiskajā līgumā, ko apstiprinājusi Latvijas Republikas Saeima, ir paredzēti citādi noteikumi nekā Latvijas likumā, piemēro starptautiskā līguma noteikumus (CPL 5. panta otrā dạ̦a). Savukārt, ja attiecīgo jautājumu regulē ES tiesību normas, kas tieši piemērojamas Latvijā, Latvijas likumu piemēro, ciktāl to pieḷauj ES tiesību normas (CPL 5. panta trešā daḷa). Jāvērš uzmanība uz to, ka CPL 5. panta ceturtajā daḷā, tāpat 
kā LPTV 18. panta noteikumos, paredzēts, ka likumā vai starptautiskā līgumā noteiktajos gadījumos tiesa piemēro arì citu valstu likumus. Tas nozīmē, ka visos gadījumos ārvalsts likuma piemērošanai ir jāizriet no likuma tā plašā izpratnē - Latvijai saistošu starptautisko līgumu, tieši piemērojamo ES tiesību aktu vai arī nacionālo tiesību normām [7].

Savukārt tajos gadījumos, kuros nav likuma, kas regulē strīdīgo attiecību, tiesa piemēro likumu, kurš regulē līdzīgas tiesiskās attiecības, bet, ja arī šāda likuma nav, vadās pēc tiesību vispārējiem principiem un jēgas (CPL 5. panta piektā daḷa).

Tiesību doktrīnā, aplūkojot jautājumu par analogiijas pielietojumu procesuālajās tiesībās, norādīts: "Kaut gan, stingri vadoties no CPL 5. panta piektajā daḷā ietvertajiem vārdiem "ja nav likuma, kas regulē strīdīgo attiecỉbu”, var nonākt pie secinājuma, ka pēc analog̣ijas piemērojamas vienīgi "materiālo tiesību normas", tas pats par sevi nevar būt pamats, lai noliegtu analog̣iju civilprocesuālajās tiesībās. Arī šajās tiesībās [..] analoǵija ir piel̦aujama" [17, 122; 20, 337]. Tas, ka zināmos apstākḷ os ar analoǵijas metodes palīdzību iespējams rast procesuālas dabas jautājuma risinājumu, atzīts arī judikatūrā $[8 ; 9 ; 10]$. Gan likums, gan tiesu prakse, kā arī tiesību doktrīna dod pamatu secinājumam, ka civilprocesā kā publiskajās tiesībās analogiija ir piemērojama un par to strīda nav.

Tomēr analogiija (juridiskā nozīmē) kā tiesību tālākveidošanas paṇēmiens tiek pielietota atklātu likuma "robu" aizpildīšanai. "Analog̣ija civilprocesā var tikt pielietota pie nosacījuma, kad ir atklāta likuma "roba" esība attiecībā uz konkrētajā gadījumā izlemjamo jautājumu" [11]. Analogiija ir viens no tiesību tālākveidošanas paṇēmieniem tiesību normas neesamības (likuma "roba") gadījumā, kurā likumā (tiesību normā) noregulētam dzīves gadījumam paredzētās tiesiskās sekas tiek attiecinātas uz likumā tieši neregulētu, bet līdzīgu dzīves gadỉjumu. Izšḳir tiesību analoǵiju un likuma analoǵiju $[19,42]$. Tādējādi gadījumā, kurā tiesa nav konstatējusi likuma "robu", analogijas (likuma vai tiesību) pielietošanai nav pamata [13].

Šeit jānorāda, ka ne visas likumos saskatāmās nepilnības ir uzskatāmas par likuma "robu", ko tiesnesim ir ne vien tiesības, bet arī pienākums "aizpildīt", lai pastāvošās tiesību sistēmas ietvaros varētu izspriest konkrētu lietu vai izlemt kādu procesuālu jautājumu [13]. Bieži konstatējami arī tiesību "robi", t. i., visas tiesību sistēmas nepilnība vai kāda tiesiskā regulējuma vai vesela tiesību institūta trūkums, kuram atbilstoši apgrozības nepieciešamībai vai vispārējās tiesiskās apziņas pieprasìtam tiesību principam vajadzētu būt ietvertam tiesību sistēmā. Tiesību "robu" aizpildīšanu var veikt tikai likumdevējs, kuram ir jāpieņem vispārīga rakstura tiesību normas. [24, 176]

Atšķiin̄bā no materiālajām tiesībām procesuālajās tiesībās tiesību avots nevar būt paražu tiesības. Tas ir tāpēc, ka tiesas stingri pamatojas uz likumā paredzētajām tiesību normām, jo procesuālās tiesības ir formālas tiesības [17, 115].

Par civilprocesa tiesību avotu nevar būt Ministru kabineta noteikumi, jo tie nevar grozìt tiesu iekārtas un procesuālos likumus. Tomēr atsevišḳus ar tiesas spriešanu un nolēmumu izpildi saistītus jautājumus var regulēt arī Ministru kabineta noteikumi [3]. 
Būtisks civilprocesa avots ir tiesu judikatūra (CPL 5. panta sestā daḷa), tostarp Eiropas Cilvēktiesību tiesas (turpmāk - ECT) judikatūra, kā arī Eiropas Savienības Tiesas (turpmāk - EST) prejudiciālie nolēmumi (sk. CPL 5. ${ }^{1}$ pantu).

Judikatūra tiek skaidrota, kā publicēto tiesas (galvenokārt Augstākās tiesas) nolēmumu kopums, kuram ir principiāla nozīme un kas satur abstrakta rakstura juridiskas atziņas (prejudīcijas). Pie judikatūras nepieder atcelti un acìmredzami kḷūdaini spriedumi, taču tie pieder pie tiesu prakses [22, 32; 25, 12]. Tomēr nav jāsaprot, ka judikatūra ir, piemēram, kāds Senāta spriedums kā tāds, bet gan tā ir šajā spriedumā izteiktā tēze vai tēzes, ko juridiskā valodā sauc par ratio decidenti. Turpretī pārējie šã sprieduma argumenti (obiter dicta) ir vērtējami kā "pa cel̦am teikti", un tiem nav judikatūras nozīmes.

Judikatūras spēks un nozīme ir tikai tādam spriedumam, kas ir stājies likumīgā spēkā un ir arī publicēts. Judikatūru, tāpat kā likumu, ir tiesības zināt ikvienam, un tai ir jābūt pieejamai jebkuram (ne tikai tiesnešiem vai citiem juristiem). Turklāt sevišķa nozīme judikatūrai ir gadījumā, ja konkrētajā jautājumā ir tā saucamais tiesību "robs" un ir radusies nepieciešamība ar interpretācijas pamatmetožu palīdzību noskaidrot likuma jēgu. Taču judikatūrā izteiktās atziṇas nevar runāt pretī spēkā esošiem likumiem $[25,12]$.

Jāatzīmē, ka judikatūra savā būtībā ir sekundārs tiesību avots un nevar būt patstāvīgs pamats prasības noraidī̌̌anai. Šajā sakarā Latvijas Republikas Augstākā tiesa ir noteikusi [5], ka nav piel̦aujama atsauce uz konkrētu lietu kā tiesu praksi, neatklājot iepriekšèjā tiesas spriedumā izvirzìtos argumentus un nenorādot, kā konkrētā lieta sasaucas ar iepriekšējā lietā pastāvējušajiem faktiskajiem un tiesiskajiem apstākḷiem, kas lauj tiesai izdarìt secinājumu par atbilstošu strīda risinājumu izskatāmajā lietā.

Savukārt, nnemot vērā Latvijas tiesību sistēmu, Eiropas Cilvēka tiesību un pamatbrīvību aizsardzības konvencija (turpmāk - ECK) var tikt piemērota gan kā materiālais tiesību avots, gan kā nacionālo normu interpretācijas līdzeklis. Tās ir divas galvenās funkcijas, kuras ECK var pildīt Senāta judikatūrā. Iespējamas ir arī citas ECK izpausmes, piemēram, kā atsauce uz vispārīgu principu jeb fakta apliecinājumu, ka attiecīgais tiesību avots pastāv, taču bez sekojošas analīzes, vai kā atsauce ar papildu argumenta nozīmi, kas apliecina tiesas veiktās analīzes pareizumu. Tomēr lielākā ECK ietekme ir iespējama, to piemērojot kā tiesību avotu vai kā nacionālo normu interpretācijas līdzekli [23, 3].

Tajos gadījumos, kuros jāpiemēro ES tiesību normas, tiesai var rasties nepieciešamỉba noskaidrot to saturu. Šeit gan jāṇem vērā, ka saskaṇā ar Līguma par ES darbību 267. pantu EST kompetencē ir sniegt prejudiciālus nolēmumus par ES tiesību interpretāciju un par ES iestāžu un struktūru pieṇemto tiesību aktu spēkā esamību. Jautājumus EST var uzdot jebkura Latvijas tiesa, kuras tiesvedībā ir civillieta un tās izspriešanai nepieciešams EST iepriekšējs izskaidrojums (CPL 5. ${ }^{1}$ pants). Turklāt, ja šāds izskaidrojums ir vajadzīgs lietā, ko izskata tiesa, kuras nolēmums saskaṇā ar likumu nav pārsūdzams, tad šai tiesai ir pienākums vērsties EST.

Civiltiesību normas tiek piemērotas, lai atrisinātu vai novērstu tiesiskos strīdus. Lai juridiski korekti piemērotu tiesību normas, bieži vien ir nepieciešama to satura iztulkošana 
jeb interpretācija [16, 50-72]. Civiltiesību normu piemērošanai un iztulkošanai jāizmanto tie paši tiesību teorijā atzītie pañēmieni kā jebkurā citā tiesību nozarē.

Civillikuma [1] (turpmāk - CL) 2. pantā noteikts, ka likums piemērojams visos tiesību jautājumos, uz kuriem attiecas tā teksts vai iztulkojums. Ieradumu tiesības nevar ne atcelt, ne grozīt likumu. Ieradumu tiesības piemērojamas likumā noteiktos gadījumos.

Katra civiltiesiskā attiecība apspriežama pēc likumiem, kas bijuši spēkā tad, kad šĩ attiecība radusies, pārgrozījusies vai izbeigusies. Neskartas paliek jau iegūtās tiesības (CL 3. pants). Saskañā ar CL 4. pantu likuma noteikumi ir iztulkojami vispirms pēc to tiešã jēguma; vajadzības gadījumā tie iztulkojami arī pēc likuma sistēmas, pamata un mērķa, un, beidzot, - arī pēc analogiijas. Savukārt, kad lietas jāizšḳir pēc tiesas ieskata vai atkarībā no svarīgiem iemesliem, tad tiesnesim jāspriež pēc taisnības apziņas un vispārīgiem tiesību principiem.

\section{Likumības principa negatīvā definīcija}

Likumības principam civilprocesā ir ne tikai pozitīva, bet arī negatīva definīcija: CPL ir ietverts uzskaitījums ar likumības principa pārkāpuma formālajām pazīmēm, proti, pazīmēm par tiesas nolēmumu nepamatotību un prettiesiskumu civillietā, t. i., ja tiesa nepareizi piemērojusi materiālo tiesību normu, pārkāpusi procesuālo tiesību normu vai, izskatot lietu, pārsniegusi savas kompetences robežas (sk. CPL 450. panta trešo dalıu).

CPL 451. pantā ir skaidrota materiālo tiesību normu nepareiza piemērošana. Tiesa materiālo tiesību normu ir piemērojusi nepareizi, ja tā nepareizi attiecināta uz tiesas konstatētajiem apstākḷiem vai ja materiālo tiesību norma nepareizi iztulkota (CPL 451. panta pirmā daḷa). Savukārt materiālo tiesību normas nepareiza piemērošana var būt pamats sprieduma pārsūdzēšanai kasācijas kārtībā, ja tā ir novedusi vai varēja novest pie lietas nepareizas izspriešanas (CPL 450. panta otrā dal̦a).

Attiecībā uz procesuālo tiesību normu pārkāpumu skaidrojums ir CPL 452. pantā. Saskaṇā ar CPL 451. panta pirmo daḷu tiesa ir piel̦āvusi procesuālās tiesību normas pārkāpumu, ja tiesvedības laikā nav nodrošinājusi likumam atbilstošu procesuālo kārtību vai personu procesuālo tiesību ievērošanu, attiecīgo tiesību normu nepiemērojot vai nepareizi iztulkojot.

Procesuālo tiesību normas pārkāpums var būt pamats sprieduma pārsūdzēšanai kasācijas kārtībā, ja tas novedis vai varēja novest pie lietas nepareizas izspriešanas (CPL 452. panta otrā dalıa).

Saskaṇā ar CPL 452. panta trešo daḷu par procesuālo tiesību normas pārkāpumu, kas varēja novest pie lietas nepareizas izspriešanas, katrā ziṇā uzskatāms tas, ka:

1) tiesa lietu izskatījusi nelikumīgā sastāvā;

2) tiesa lietu izskatījusi, pārkāpjot procesuālo tiesību normas, kas nosaka pienākumu paziņot procesa dalïbniekiem par tiesas sēdes laiku un vietu;

3) pārkāptas procesuālo tiesību normas par tiesvedības valodu; 
4) tiesas spriedums piešḳir tiesības vai uzliek pienākumus personai, kura nav pieaicināta lietā kā procesa dalībnieks;

5) lietā nav tiesas sēdes protokola vai tiesas sprieduma.

Lai gan atbilstoši CPL 426. panta trešajai daḷai apelācijas instances tiesa izskata lietu pēc būtības, nenosūtot to jaunai izskatîšanai pirmās instances tiesai, izṇēmums noteikts CPL 427. pantā, t. i., apelācijas instances tiesa neatkarīgi no apelācijas sūdzības motīviem ar lēmumu atcel pirmās instances tiesas spriedumu un nosūta lietu jaunai izskatīšanai pirmās instances tiesā, ja apelācijas instances tiesa konstatē CPL 452. panta trešajā dạ̦ā minētos gadỉjumus.

\section{Likumības principa procesuālās garantijas}

Likumības principa īstenošanu nodrošina ar attiecīgām procesuālām garantijām. Tās, pirmkārt, ietver paša civilprocesa organizatoriskos un funkcionālos principus. Tas viss tieši vai netieši kalpo likumības principa īstenošanai. Tādējādi likumības principu civilprocesā var saprast kā tā organizatorisko un funkcionālo principu konsekventas istenošanas rezultātu.

Otrkārt, šā principa realizāciju nodrošina arī procesuālie līdzekḷi juridisko kḷūdu labošanai: pārskatīšanas stadija tiem nolēmumiem, kuri nav stājušies likumīgā spēkā (apelācijas un kasācijas tiesvedība, blakus sūdzības kārtība); kā arī pārskatīšanas stadija tiem nolēmumiem, kuri stājušies spēkā (jauna izskatīšana to būtisku materiālo, procesuālo tiesību normu pārkāpumu dēl, lietas jauna izskatî̌ana sakarā ar nolēmuma pārskatīšanu ES tiesību normās paredzētajos gadỉjumos un sakarā ar jaunatklātajiem apstākḷiem).

Treškārt, likumības principu garantē procesuālie līdzekḷi, kas nodrošina tiesu iestāžu pieejamību, tiesas sastāva veidošanu un procesuālo darbību formu: pienākums pazinnot iesaistītajām personām par lietas izskatî̌anas laiku un vietu; iespēja noraidīt tiesnesi; pusei ir iespēja izmantot pārstāvi; skaidrs prasības pieteikuma formas un satura regulējums; ierobežots pamatojumu saraksts atteikumam pieteikuma pienemšanai; tiesas sprieduma forma un saturs $\mathrm{u}$. tml.

Ceturtkārt, likumības principu nodrošina procesuālie līdzekḷi lietas faktisko apstākḷu noteikšanai. Civilprocesa mērḳis - lietas izskatǐšanas rezultātā noskaidrot lietas faktiskos apstākḷus un tiem pareizi piemērot materiālo tiesību normu. Likumības principu nevar uzskatìt par īstenotu, ja konkrētā gadījumā tiesa nav pilnībā un pareizi noteikusi lietas faktiskos apstākḷus, pušu tiesības un pienākumus. Piemēram, CPL 193. panta piektajā daḷā noteikts, ka sprieduma motīvu daḷā norāda lietā konstatētos faktus un pierādījumus, ar kuriem tiek pamatoti tiesas secinājumi, kā arī argumentus, ar kuriem noraidīti tie vai citi pierādījumi, un norāda arī normatīvos aktus, pēc kuriem tiesa vadījusies, un konstatēto lietas apstākḷu juridisko novērtējumu, kas nozīmē to, ka tiesas konstatētie faktiskie apstākḷi, veicot to juridisko analīzi, ir jāietver kādas konkrētas tiesību normas sastāvā [12]. 
Visbeidzot, juridiskajā literatūrā atzīts, ka "[..] tiesa še vispirms konstatē, vai prāvnieku (galvenā kārtā prasītāja) uzdotie apstākḷi, uz kuriem pamatoti pušu prasījumi, izrādījušies par patiesiem un kādas juridiskas sekas likums saista ar noskaidrotiem apstākḷiem" [17, 431]. Lìdz ar to pareiza likuma piemērošana vienmēr balstās uz procesuālās darbības, kurā tiek noteikts pušu subjektīvo tiesību un pienākumu rašanās, izmaiṇas vai izbeigšanas pamats, tas ir, kurā tiek noteikti juridiski fakti. Tādējādi izziṇas process tiesās ietver arī tiesas konstatēto faktu juridisku novērtējumu.

\section{Secinājumi}

Likumības princips ietver, pirmkārt, prasību tiesām pareizi piemērot materiālo tiesību normas un veikt procesuālās darbības atbilstoši tiesību normām; otrkārt, prasību citiem procesa dalībnieki ievērot procesuālo un materiālo tiesisko regulējumu, iztiesājot un izskatot civillietu tiesā. Tādējādi likumỉbas princips ietver procesuālās un materiālās sastāvdaḷas. Turklāt likumības principam civilprocesā ir ne tikai pozitīva, bet arī negatīva definīija.

\section{Principle of Legality in Civil Procedure: Basis for Formal Conduct of Civil Cases}

\section{Abstract}

In the article, the author examines the matter of the expression and content of the principle of legality in civil procedure, more specifically focusing on the procedural and substantive problems of the principle of legality.

Civil procedure is universal as a compulsory form of protection of subjective rights or, in other words, civil procedure is a procedure for compulsory exercise of civil rights, which is reduced to a set of norms that determine the type of actions of both existing legal protection institutions and persons who use this protection or are involved in it in any other way. Legality plays an important role in this regard. Legality means a state of life of the society which, firstly, has a legal framework, which is not logically contradictory and which generally meets the objective needs of this society and, secondly, natural and legal persons respect and follow the legal norms adopted.

In civil procedure, this is not only a principle, but also one of the aims of legal proceedings. According to its content, the principle of legality includes, firstly, the requirement that the courts apply the norms of the substantive law correctly and carry out procedural actions in accordance with the legal norms; secondly, the requirement that other participants of the procedure comply with the procedural and substantive legal regulation when adjudicating and considering civil cases in court. Thus, the principle of legality includes procedural and substantive components. 
The aim of the article is, by analysing the moral-legal content of the principle of legality, to evaluate the aspects of its application. Material and methods used in the study for the empirical basis of the research include scientific works and collections of articles, publications in periodicals and primary sources, laws, internet resources, as well as other publicly available information. Analytical, inductive and deductive research methods have been used in the research.

Keywords: civil procedure, legal proceedings in civil cases, principle of legality.

\section{Avoti un literatūra}

\section{Tiesību akti}

1. Civillikums: Latvijas Republikas likums. Valdības Vēstnesis. 41, 20.02.1937.

2. Civilprocesa likums: Latvijas Republikas likums. Latvijas Vēstnesis. 326/330, 03.11.1998.

3. Noteikumi par atlīdzināmajiem tulka izdevumiem civilprocesā: Latvijas Republikas Ministru kabineta 21.05.2016. noteikumi Nr. 346. Latvijas Vèstnesis. 109, 07.06.2016.,

4. Par tiesu varu: Latvijas Republikas likums. Ziṇotājs. 1, 14.01.1993.

\section{Tiesu prakse}

5. Latvijas Republikas Augstākās tiesas 28.02.2007. spriedums lietā Nr. SKC-89.

6. Latvijas Republikas Augstākās tiesas 26.06.2009. lēmums lietā Nr. SKC-848.

7. Latvijas Republikas Augstākās tiesas 01.07.2015. spriedums lietā Nr. SKC-90/2015.

8. Latvijas Republikas Augstākās tiesas 23.03.2016. lēmums lietā Nr. SKC-1403/2016.

9. Latvijas Republikas Augstākās tiesas 24.11.2017. lēmums lietā Nr. SKC-1023/2017.

10. Latvijas Republikas Augstākās tiesas 18.12.2017. lēmums lietā Nr. AKC-1841/2017.

11. Latvijas Republikas Augstākās tiesas 21.02.2018. lēmums lietā Nr. SKC-407/2018.

12. Latvijas Republikas Augstākās tiesas 06.02.2019. spriedums lietā Nr. SKC-87/2019.

13. Latvijas Republikas Augstākās tiesas 13.12.2019. lēmums lietā Nr. SKC-1541/2019.

14. Latvijas Republikas Satversmes tiesas 17.01.2002. spriedums lietā Nr. 2001-08-01 "Par Civilprocesa likuma 348. panta septītās daḷas atbilstību Latvijas Republikas Satversmes 92. pantam”, 1. tēze. Latvijas Vēstnesis. 10(2585), 18.01.2002.

15. Latvijas Republikas Satversmes tiesas 02.06.2008. spriedums lietā Nr. 2007-22-01 "Par Civilprocesa likuma 434. un 464. panta atbilstību Latvijas Republikas Satversmes 1., 82., 86. un 92. pantam", 17.2. tēze. Latvijas Vèstnesis. 89(3873), 10.06.2008.

\section{Literatūra}

16. Balodis, K. 2007. Ievads civiltiesībās. Rīga: Zvaigzne ABC.

17. Bukovskis, V. 1933. Civīlprocesa mācības grāmata. Rìga: Autora izdevums.

18. Civilprocesa likuma komentāri. Aut. kol. prof. K. Torgāna vispārīgā zin. red. Rīga: Tiesu namu aǵentūra, 2006.

19. Civilprocesa likuma komentāri. I daḷa (1.-28. nodaḷa). Aut. kol. prof. K. Torgāna zin. red. Rīga: Tiesu namu aǵentūra, 2016.

20. Kalninšs, E. 2005. Privāttiesību teorija un prakse. Rīga: Tiesu namu aǵentūra.

21. Konradi, F., Zvejnieks, T. 1939. Civilprocesa likums (1938. g. izd., 1939. gada iesp.) ar paskaidrojumiem. Rīga: Valsts tipogrāfija. 
Ivars Kronis. Likumības princips civilprocesā: formālas lietu vešanas kārtības pamats civillietās

22. Levits, E. Judikatūra - pamati, problēmas, piemērošana. Latvijas Republikas Augstākās tiesas bil̦etens. 1, 2010.

23. Mits, M. Eiropas Cilvēktiesību tiesas judikatūra Augstākās tiesas nolēmumos. Latvijas Republikas Augstākās tiesas biḷetens. 6, 2013.

24. Neimanis, J. 2004. Ievads tiesībās. Rīga: Zv. adv. J. Neimanis.

25. Zemrībo, G. 2010. Priekšvārds. No: Zvērinātu advokātu birojs "BDO Zelmenis \& Liberte”. Darba likums ar komentāriem. Rīga: Latvijas Brīvo arodbiedrību savienība. 